\title{
Study of the Socio-economic Characteristics of BT Cotton Farmers in Beawer Area in Ajmer District of Rajasthan, India
}

\author{
Sanjiv Kumar ${ }^{1,2^{*}}$, C.R. Bharodia ${ }^{1}$, Sarita Meena ${ }^{2}$ and Bhupendr Singh Tyagi ${ }^{2}$ \\ ${ }^{1}$ Post Graduate Institute of Agri-Business Management, Junagadh Agriculture University, \\ Junagadh-362001, India \\ ${ }^{2}$ Jagannath Agriculture University, Chaksu, Jaipur, India \\ *Corresponding author
}

\section{A B S T R A C T}

\begin{tabular}{|l|}
\hline Ke y w o r d s \\
BT cotton farmers, \\
$\begin{array}{l}\text { Socio- economic } \\
\text { characteristics, } \\
\text { Pricing policy }\end{array}$ \\
\hline Article Info \\
\hline $\begin{array}{l}\text { Accepted: } \\
\text { 12 October } 2019 \\
\text { Available Online: } \\
\text { 10 November } 2019\end{array}$ \\
\hline
\end{tabular}

\section{Introduction}

Indian Seed Industry has shown a significant growth in size and level since its inception. It is growing at the rate of 12.00 per cent compared to less than 5 per cent growth of global seed market. Both public and private cotton.
A survey was conducting during 2015 to study of the socio- economic characteristics of BT cotton farmers in Beawer area in Ajmer district of Rajasthan. According to this study the highest number of farmers (43) belonged to age group of 40 to 50 years, followed by 37 farmers belonged to the age group of below 40 years and 20 farmers belonged to the age group of above 50 years. The majority of farmers i.e., 49 were medium farmers, followed by 29 farmers were large farmers, 22 farmers were small farmers. In the study area, 92 farmers were married and remaining 8 farmers were unmarried. The majority of farmers i.e., 61 had the education up to higher secondary level, followed by 15 farmers that were illiterate, 13 farmers were up to primary level and only 11 farmers were graduates. The 63 farmers were used to live in nuclear family and 37 farmers used to live in joint family. The highest number of farmers (62) had 2 to 5 members in their family, followed by 24 farmers had above 5 family members in the family and 14 per cent farmers had 2 members in the family. The majority of farmers i.e., 55 farmers belonged to the income range between to Rs. 60,000 to 100000 , followed by 31 farmers belonged up to Rs. 60,000 and only 14 farmers belonged above Rs. 1,00,000. The majority of farmers i.e., 55 farmers were from Other Backward Class (OBC), followed by 28 farmers were belonged to other categories like Schedule Caste (SC), Schedule Tribe (ST) and only 17 farmers were belonged to open category. This study helps companies to decide pricing policy for BT 
(sales turnover less than Rs. 20 million) with local presence. More than 40 companies have Govt. recognition for their R\&D units.

The share of private sector in value is greater than its share in volume because of its focus on production of high value hybrids and currently, some 500 hybrids of field crops and vegetables are being marketed, as truthfully labelled seeds, mostly by private seed companies.

Cotton is one of the major fibre crops of global significance. It is cultivated in tropical and sub tropical regions of more than eighty countries of world occupying nearly $33 \mathrm{~m}$ ha with an annual production of 19 to 20 million tonnes of bales. China, USA, India, Pakistan, Uzbekistan, Australia, Brazil, Greece, Argentina and Egypt are major cotton producing countries. These countries contribute nearly 85.00 per cent of the global cotton production. In India, cotton is being cultivated in $9 \mathrm{~m}$ ha and stands first in acreage. Nearly 60 million people are engaged in cotton production, marketing and processing. The textile industry which utilizes the cotton provides employment to about 16.00 per cent of the total workforce.

In cotton, the first transgenic plant was developed in 1987 in USA by Monsanto, Delta and Pine companies. Later on, the research work on development of transgenic was intensified all over the globe and several transgenic plants were developed. The introduction of BT cotton has provided growers with a new tool for managing bollworms in cotton. Numerous benefits of this technology accrue to the grower, the global cotton industry, and society on many levels-economic, environmental and social. These benefits include direct benefits, such as reduced pesticide use, improved crop management effectiveness, reduced production costs, improved yield and profitability, reduction in farming risk and improvement opportunity to grow cotton in areas of severe pest infestation. Indirect significant benefits of the technology include improved populations of beneficial insects and wildlife in cotton field, reduced pesticides runoff, air pollution and waste from the use insecticides, improved farm worker and neighbour safety, reduction in labour costs and time, reduction in fossil fuel use and improved soil quality. The most significant benefit of biotech cotton to date has been the reduction in insecticidal usage for the control of certain bollworms.

The major advantages of BT cotton are summarized below:

The BT cotton has inbuilt genetic resistance to bollworms and is very effective in controlling the yield losses caused by bollworms to a considerable extent. The resistance is governed by a single dominant gene.

Use of BT cotton reduces use of pesticides resulting in reducing the cost of cultivation.

It results in improvement of yield levels and also improves margin of profit to the farmers.

It provides opportunities to grow cotton in areas of severe bollworm incidence.

It promotes eco-friendly cultivation of cotton and allows multiplication of beneficial insects i.e., parasites and predators of bollworms.

It also reduces environmental pollution and risk of health hazards associated with use of insecticides because in BT cotton the insecticides are rarely used.

That's why this study was carried to study the socio- economic characteristics of BT cotton farmers in Beawer area in Ajmer district of Rajasthan which helps the companies to 
decide pricing policy for BT cotton.Beawar is located at $26.1^{\circ} \mathrm{N} 74.32^{\circ} \mathrm{E}$. It has an average elevation of 439 meters (1440 feet). As of 2011, the population of Beawar is 342,935.It is located 184 kilometers (114 mi) southwest of the state capital Jaipur, amidst Aravali hills. The city used to be a major center of trade, especially in raw cotton, and used to have cotton presses and the Krishna cotton mills. Beawar is a hub of small scale industry generating revenue in crores. Beawar is larger than many present district headquarters of Rajasthan. There has been demand for creating a Beawar district over the last two decades. Majority of employment is provided by RIICO.

\section{Materials and Methods}

Nature and sources of data

\section{Primary data}

In this study purposive sampling method was used for the selection of farmers and dealers according to those who use different varieties of seeds to define sampling unit through the personal interview of dealers and farmers using well-structured questionnaires. The questions were asked according to the selected objectives.

\section{Secondary data}

In the study, secondary data was collected from interaction with the company personals, brochures, review and internet were used to emphasize more on this project work.

\section{Sample selection}

Multi stage sampling technique was adopted as per the objectives of the study. Two levels of multi stage sampling at dealers and farmers' level was taken. At the first stage of sampling, 10 dealers were selected from Beawer area of Ajmer district. In the next stage of sampling, 10 farmers per dealer were selected. Hence in this way, total 10 dealers and 100 farmers were selected from the study area.

\section{Data analysis}

To study the socio-economic condition of farmers in Beawer area, tabular method, percentage analysis, pie chart and bar diagrams were used. The parameters included for the study of socio economic profile of the sample farmers are given below.

Age of Farmers

Status of Sample Farmers According to Land Holding

Marital Status

Education Level of Sample Farmers

Family Type of Sample Farmers

Family size of Sample Farmers

Annual Income of Sample Farmers

Social Class of Sample Farmers

\section{Results and Discussion}

\section{Age of farmers}

The age of sample farmers in Beawer area in Ajmer district is presented in table 1. The farmers were divided in three age groups i.e. above 50, between 40-50 and below 40 .

Figure 1 depicts that the highest number of farmers 43 per cent belonged to age group of 40 to 50 years, followed by 37 per cent farmers belonged to the age group of below 40 years and 20 per cent farmers belonged to the age group of above 50 years. This concluded that maximum number of farmers were from 
the age group of below 40 years. This finding agrees with the finding of Onu and Edon (2009) who reported a significant relationship between farmers' age and efficiency.

They further stated that younger farmers have the tendency to operate more efficiently on the farm than the older ones because the younger farmers are more agile and energetic to work on farm.

\section{Status of sample farmers according to land holding}

Status of sample farmers according to land holding is presented in table 2. The distribution of farmers were small, medium and large i.e. the farmers had landholdings between 1-2 ha considered as small, between 2-5 ha considered as medium and above 5 ha considered as large farmers.

The figure 2 depicts that the majority of farmers i.e. 49 per cent had medium size land holdings, followed by large i.e. 29 per cent and the lowest of small i.e. 29 per cent with small size holdings. This concluded that the majority of farmers i.e., 49 were medium farmers this result is in consonance with the findings by Ibrahim (2008) who reported a mean farm size of 3 ha.

\section{Marital status of sample farmers}

The marital status of surveyed farmers in Beawer area in Ajmer district is presented in table 3. The table is categorized into two groups i.e. married and unmarried group.
Figure 3 shows the marital status of the sample farmers in Baewar area in Ajmer district. So from the figure, 92 per cent of the farmers were found married while only 8 per cent of the farmers in that area were found unmarried. The reason behind this ratio was that in the state like Rajasthan the marriage is done in early ages and next the majority in that district was below 40 years and this comes under the middle age of human life cycle.

\section{Education level of sample farmers}

The education level of sample farmers in Beawer area in Ajmer district is presented in table 4.Education level was categorized as illiterate, up to primary, up to higher secondary and graduate.

The figure 4 shows that the majority of farmers i.e., 61 per cent had the education up to higher secondary level, followed by 15 per cent farmers that were illiterate, 13 per cent farmers were up to primary level and only 11 per cent farmers were graduate. This concluded that majority of the farmers were educated up to higher secondary level hence the literacy rate of farmers was good in the Baewar of Ajmer district of Rajasthan. The results are accordance with the other scientists Alam et al., (2013) who reported that most cotton farmers in the study area are literate and will find it easy to understand and adopt new technological innovations and method of production and hence are likely to be efficient in their production.

Table.1 Age pattern of BT cotton farmers

\begin{tabular}{|c|c|}
\hline Age Distribution & Number of respondents \\
\hline Above 50 & 20 \\
\hline between 40-50 & 43 \\
\hline below 40 & 37 \\
\hline Total & 100 \\
\hline
\end{tabular}

(Source: Compiled from field survey) 
Table.2 Status of sample farmers according to landholding

\begin{tabular}{|c|c|}
\hline Farmers distribution & Number of farmers \\
\hline Small & 22 \\
\hline Medium & 49 \\
\hline Large & 29 \\
\hline Total & 100 \\
\hline
\end{tabular}

(Source: Compiled from field survey)

Table.3 Marital status of sample farmers

\begin{tabular}{|c|c|}
\hline Marital Status & Number of farmers \\
\hline Married & 92 \\
\hline Unmarried & 8 \\
\hline Total & 100 \\
\hline
\end{tabular}

(Source: Compiled from field survey)

Table.4 Level of education of BT cotton farmers

\begin{tabular}{|c|c|}
\hline Educational qualification & Number of farmers \\
\hline Illiterate & 15 \\
\hline Up to primary & 13 \\
\hline Up to higher secondary & 61 \\
\hline Graduate & 11 \\
\hline Total & 100 \\
\hline
\end{tabular}

(Source: Compiled from field survey)

Table.5 Family type of sample farmers

\begin{tabular}{|c|c|}
\hline Family type & Number of farmers \\
\hline Joint family & 37 \\
\hline Nuclear family & 63 \\
\hline Total & 100 \\
\hline
\end{tabular}

(Source: Compiled from field survey)

Table.6 Distribution of BT cotton farmers based on the size of family

\begin{tabular}{|c|c|}
\hline Size of family & Number of farmers \\
\hline 2 members & 14 \\
\hline 2 $\mathbf{- 5}$ members in the family & 62 \\
\hline Above $\mathbf{5}$ members in the family & 24 \\
\hline Total & 100 \\
\hline
\end{tabular}

(Source: Compiled from field survey) 
Table.7 Annual income of sample farmers

\begin{tabular}{|c|c|}
\hline Income per year & Number of farmers \\
\hline Up to 60000 & 31 \\
\hline Between 60000 to $\mathbf{1 0 0 0 0 0}$ & 55 \\
\hline Above 100000 & 14 \\
\hline Total & 100 \\
\hline
\end{tabular}

(Source: Compiled from field survey)

Table.8 Social class of sample farmers

\begin{tabular}{|c|c|}
\hline Social Class of Sample Farmers & Number of farmers \\
\hline Open category & 17 \\
\hline OBC & 55 \\
\hline SC & 12 \\
\hline ST & 16 \\
\hline Total & 100 \\
\hline
\end{tabular}

(Source: Compiled from field survey)

Fig.1 The age of sample farmers in Beawer area in Ajmer district

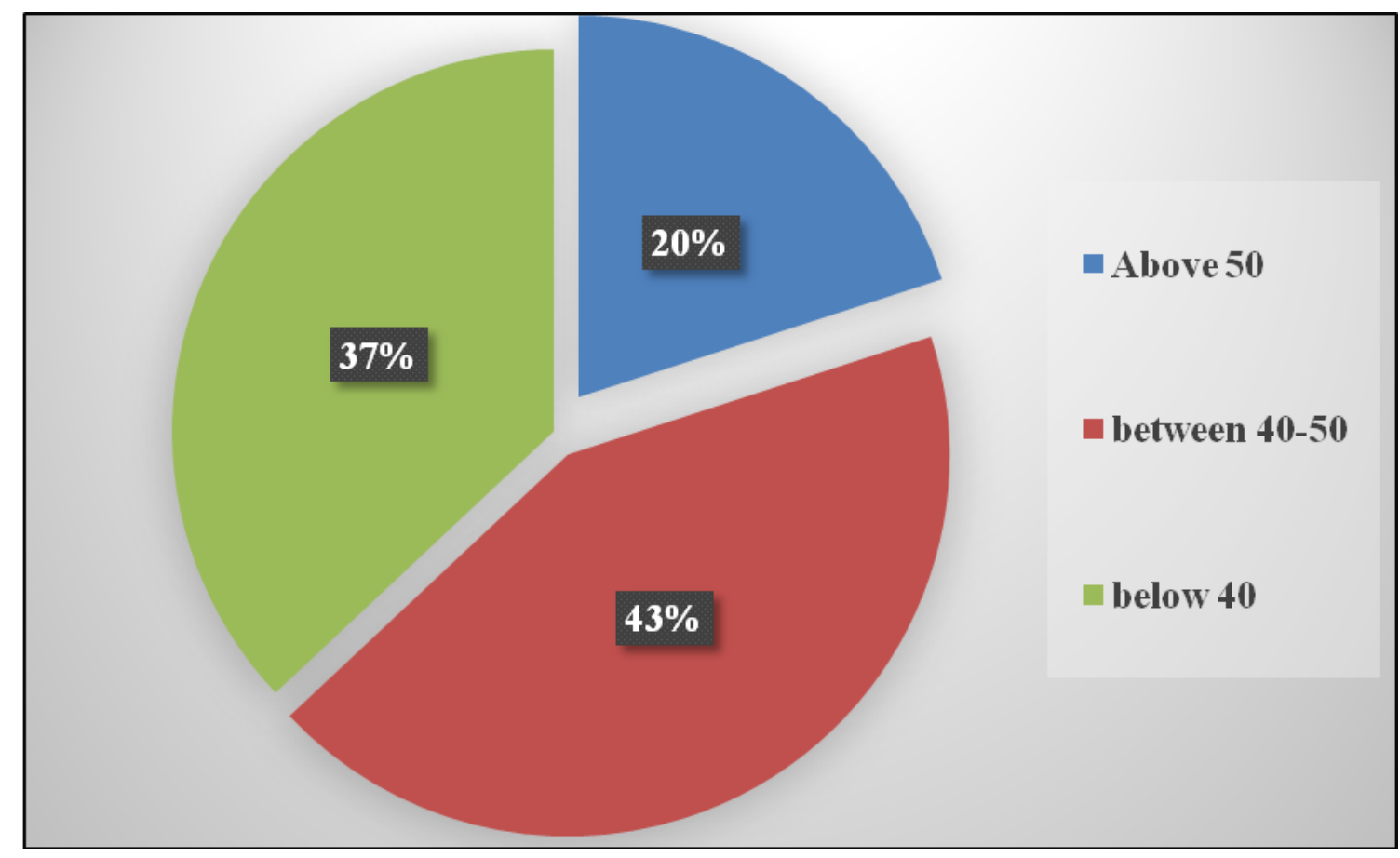


Fig.2 Status of sample farmers according to land holding in Beawer area in Ajmer district

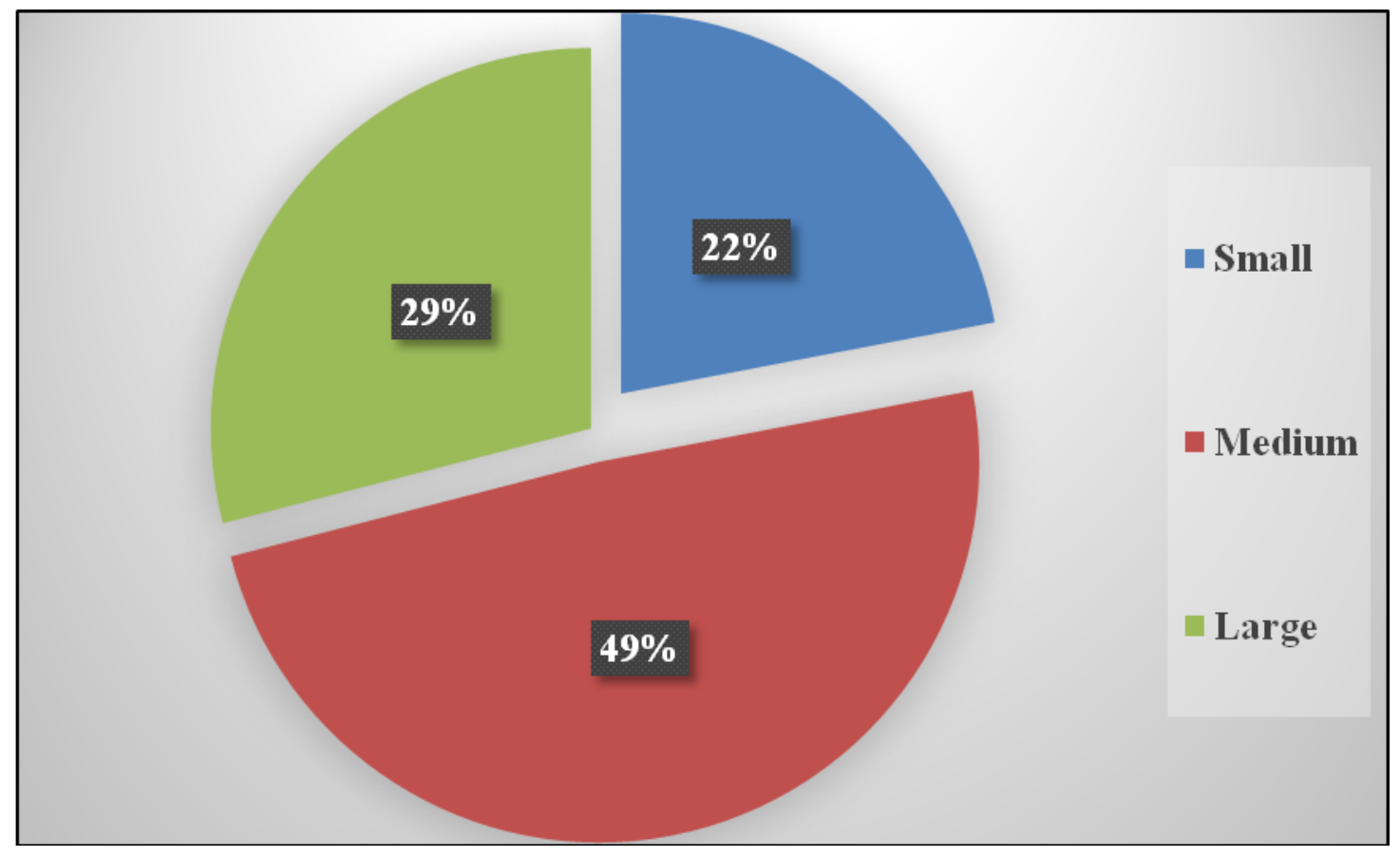

Fig.3 Marital status of sample farmers in Beawer area in Ajmer district

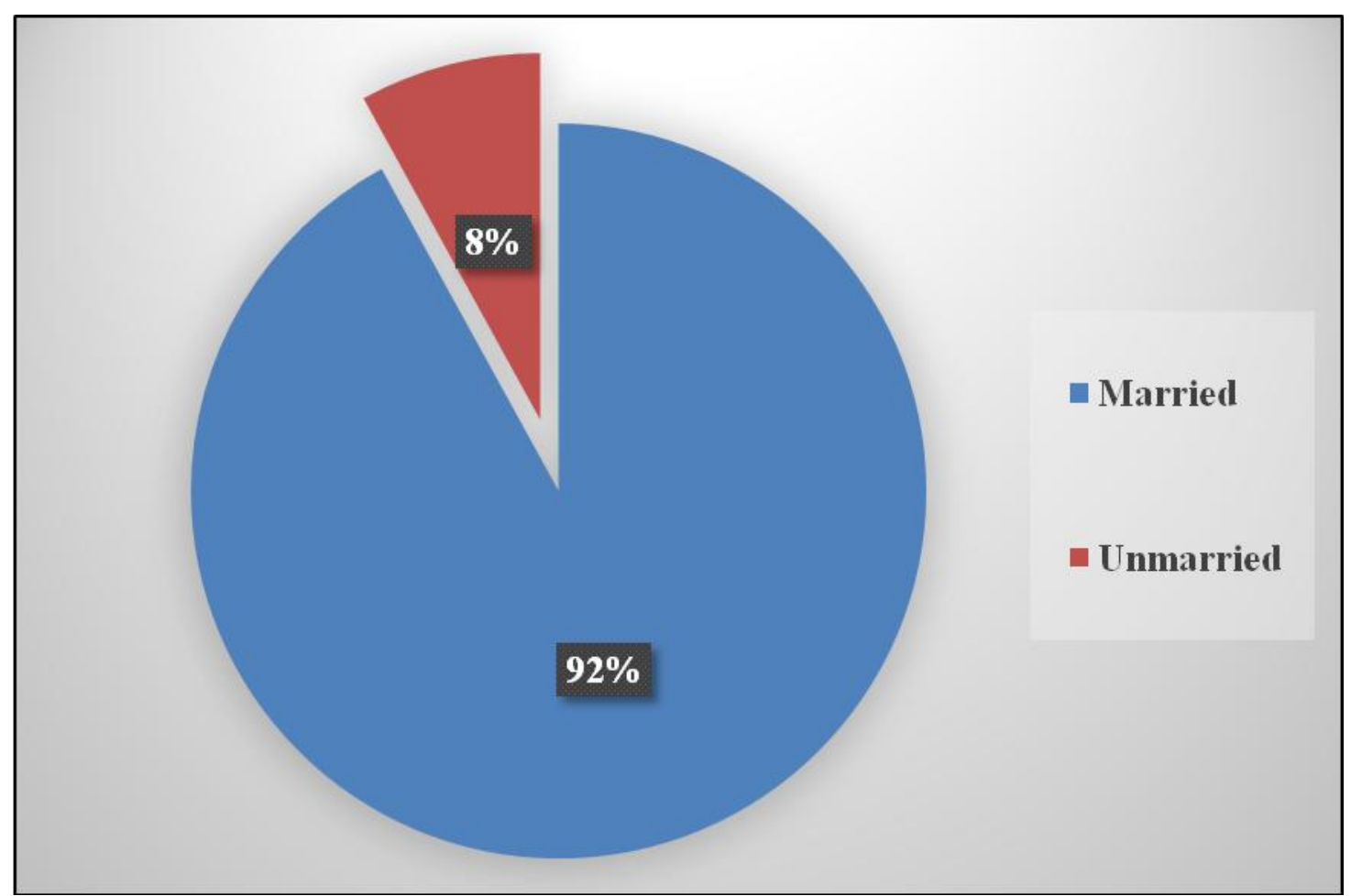


Fig.4 Education levels of sample farmers in Beawer area in Ajmer district

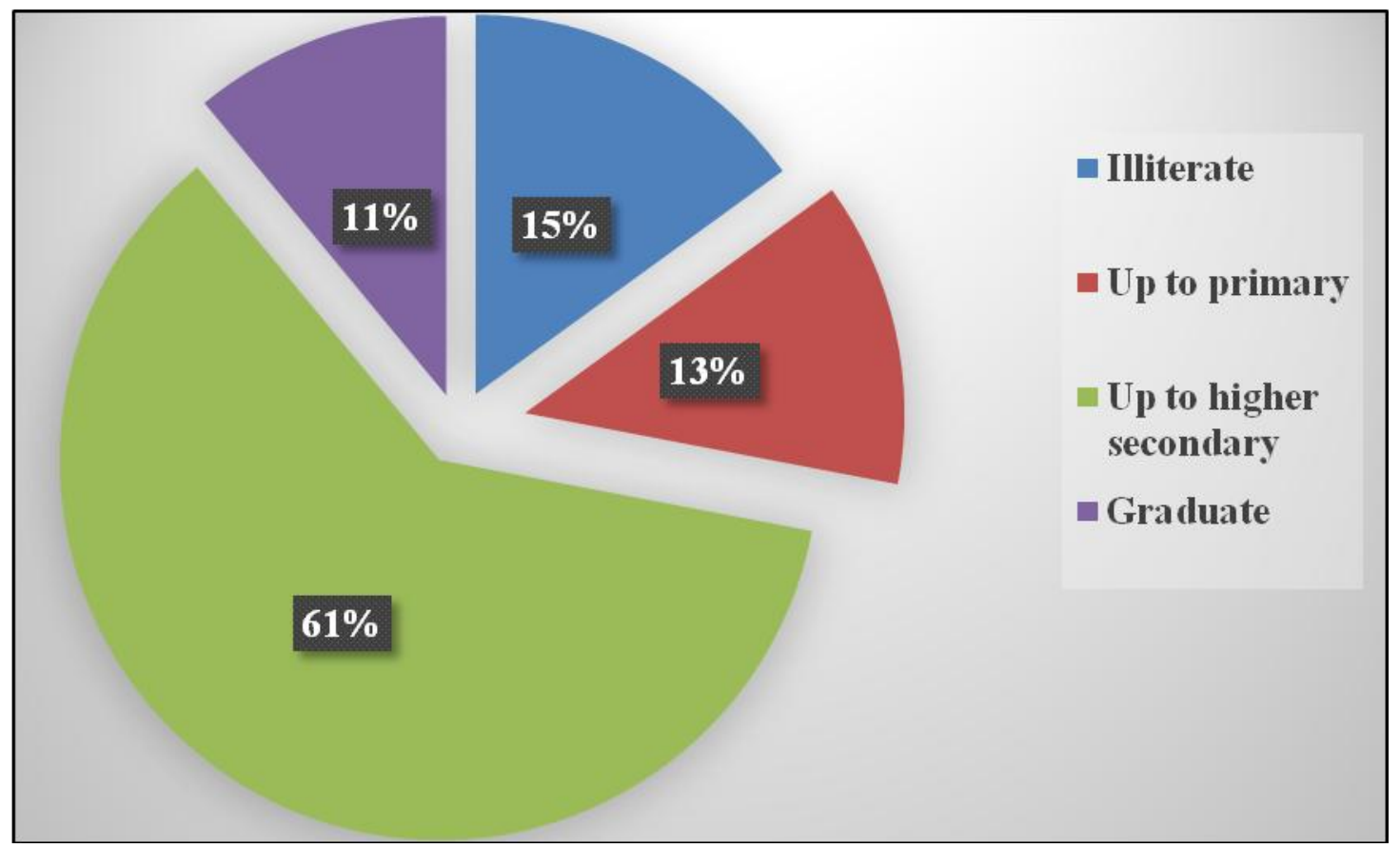

Fig.5 Family types of sample farmers in Beawer area in Ajmer district

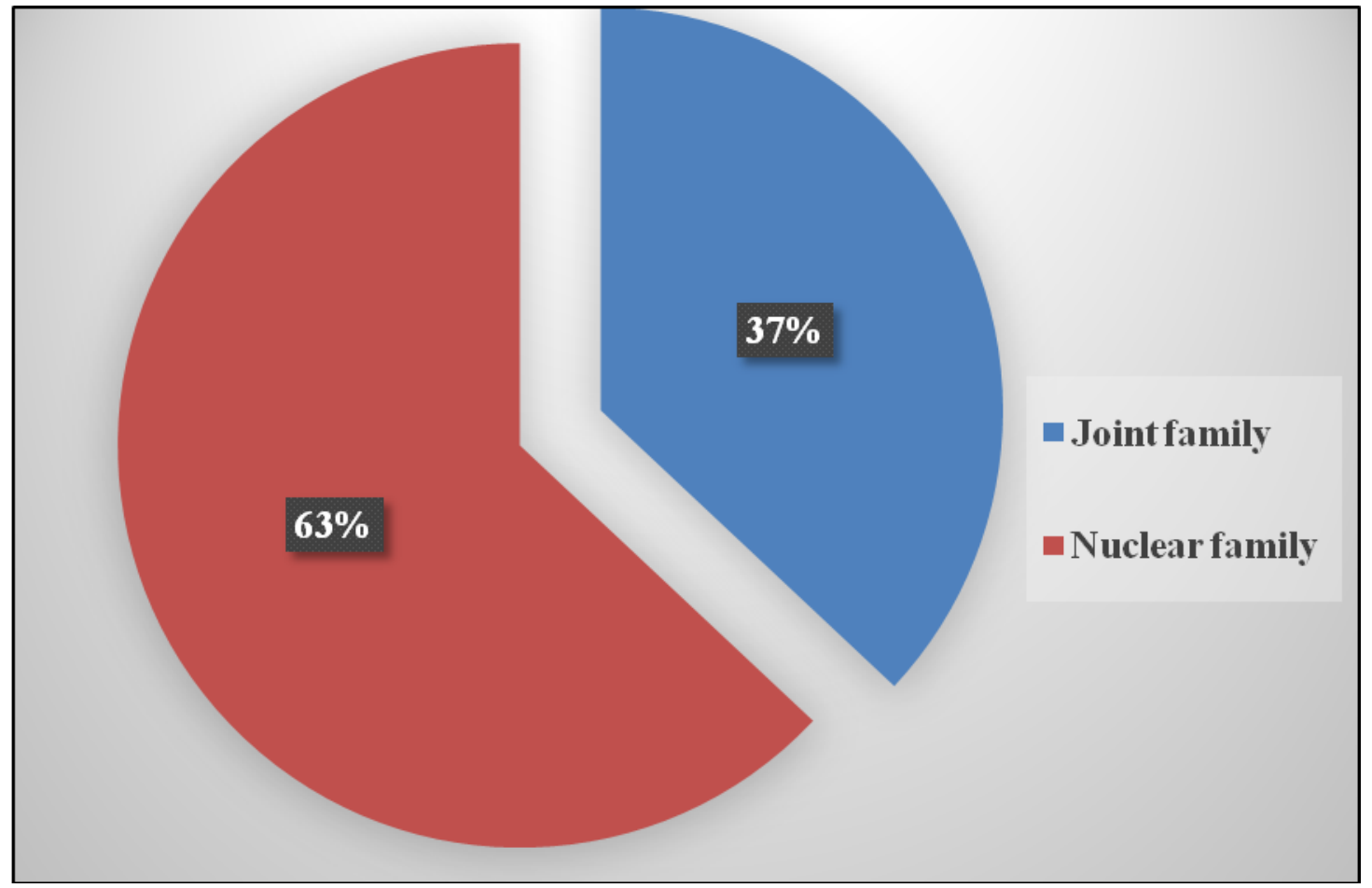


Fig.6 Family size of sample farmers in Beawer area in Ajmer district

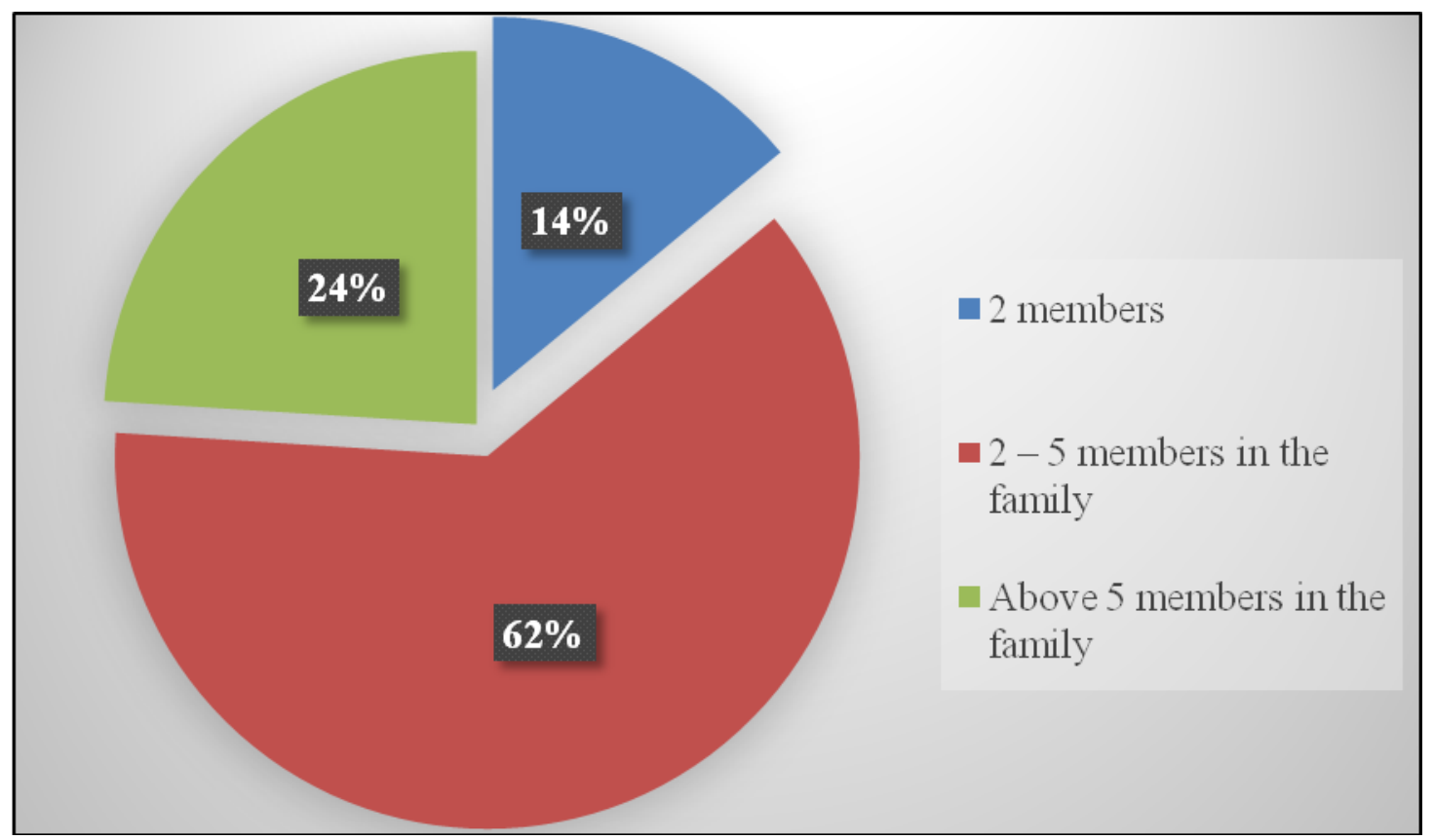

Fig.7 Annual Income of Sample Farmers in Beawer area in Ajmer district

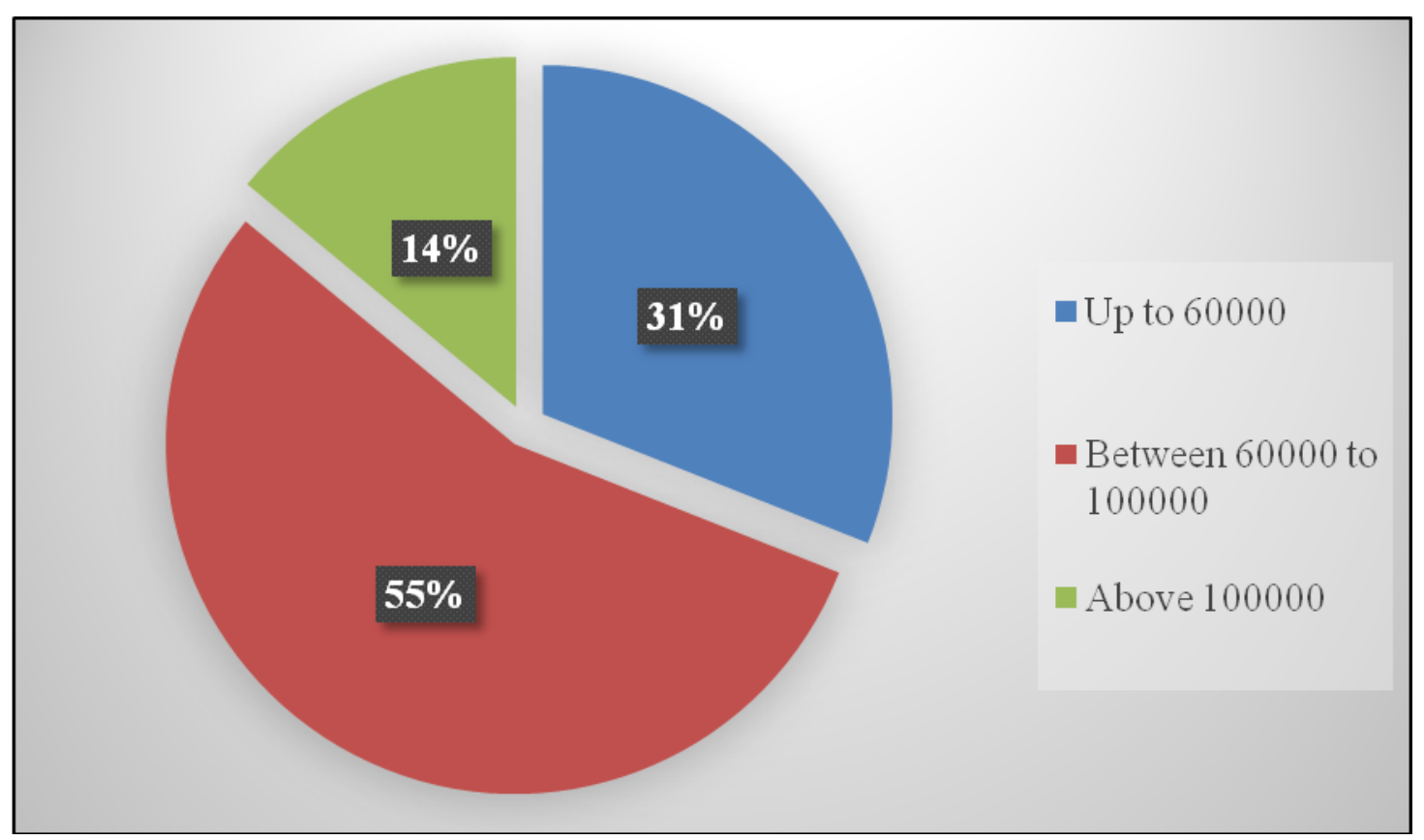


Fig.8 Social class of sample farmers in Beawer area in Ajmer district

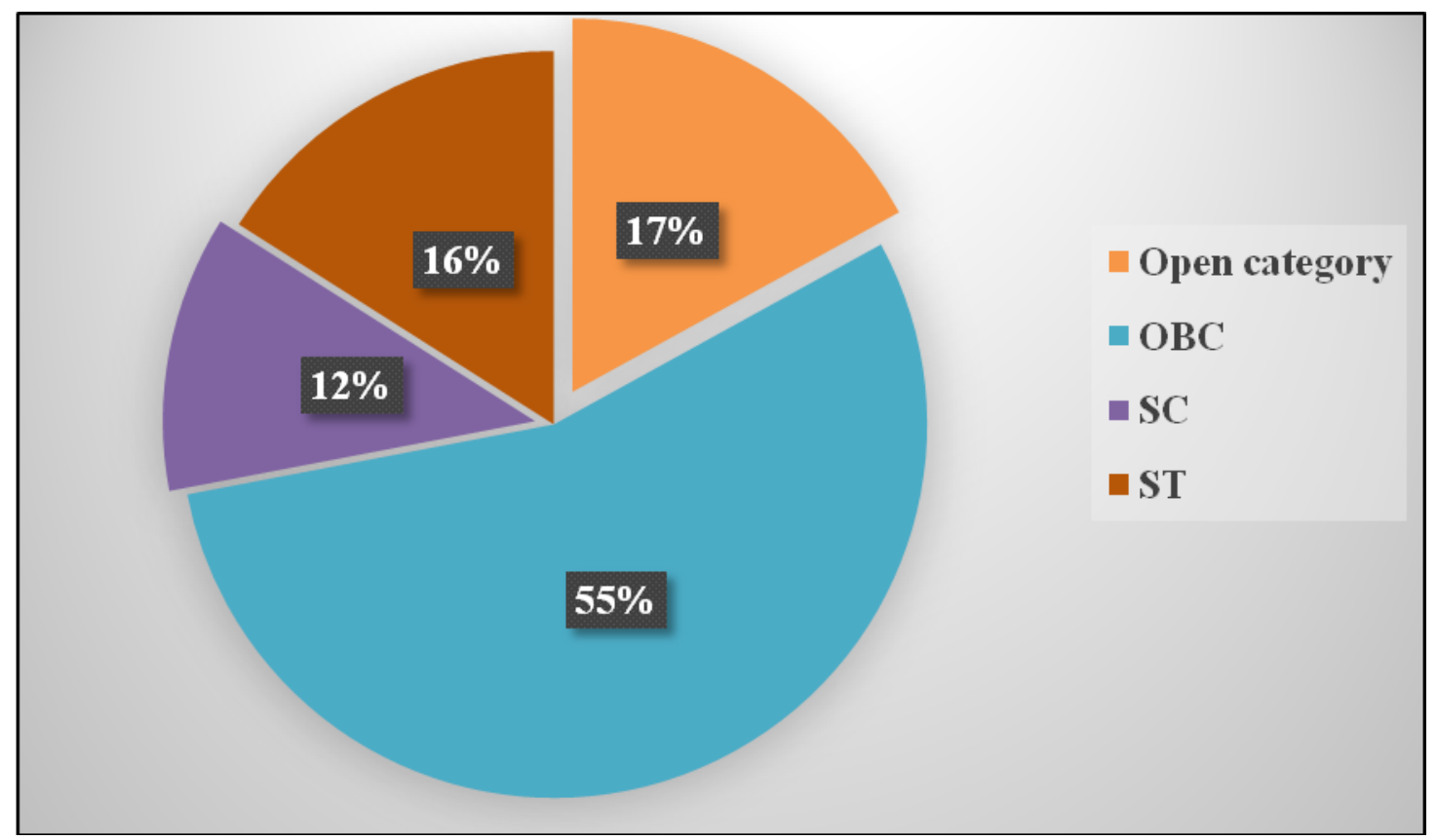

\section{Family type of sample farmers}

The family type of sample farmers in Beawer area in Ajmer district is shown in table 5. There were two categories i.e. joint family and nuclear family.

The figure 5 shows that the majority of farmers i.e. 63 per cent farmers were used to live in nuclear family and rest 37 per cent farmers used to live in joint family. The reason behind this was that farmers thinking that if the family will be separated than it will be peaceful to stay without any family violence.

This finding is in conformity with the finding of Ibrahim (2002) and Alam et al., 2013 who reported that family size is relevant to cotton production because it constitutes the highest supply of labour in cotton production. It is believed that where family labour supply is high, then cost of total production will be reduced.

\section{Family size of sample farmers}

The family size surveyed/sample farmers in Beawer area in Ajmer district is presented in table 6 . The category were 2 members, $2-5$ members and above 5 members.

Figure 6 depicts that the majority of farmers i.e. 62 per cent had 2 to 5 members in their family, followed by 24 per cent farmers had above 5 family members in the family and 14 per cent farmers had 2 members in the family. It is concluded that the majority 62 per cent had between 2- 5 members in the family. This finding is in conformity with the finding of Ibrahim (2002) and Alam et al., 2013 who reported that family size is relevant to cotton production because it constitutes the highest supply of labour in cotton production. It is believed that where family labour supply is high, then cost of total production will be reduced. 


\section{Annual income of sample farmers}

The annual income of the sample farmers is presented in table 7 . The categories were like up to 60000 , between 60000 to 100000 and above 100000 .

Figure 7 depicts that the majority of farmers i.e., 55 per cent farmers belonged to the income range between Rs. 60,000 to 100000 , followed by 31 per cent farmers belonged up to Rs. 60,000 and only 14 per cent farmers belonged to the annual income level above Rs. $1,00,000$. It is conclude that the majority of the farmers $(55 \%)$ had annual income between 60000 i.e. there is need to increase annual income by adopting various modern techniques and method so that they could increase their annual income.

\section{Social class of sample farmers}

The social class of the sample farmers is presented in Table 8. The groups were like open category, OBC, SC and ST.

Figure 8 depicts that the majority of farmers i.e., 55 percent farmers were from Other Backward Class (OBC), followed by 17 per cent farmers were belonged to open, next 16 percent farmers belonged to ST categories and the lowest of 12 percent farmers belonged to $\mathrm{SC}$ categories. It is concluded that majority of the farmers were belonged to the group of $\mathrm{OBC}$ i.e. 55 per cent in the Baewar region of the Ajmer district of Rajasthan.

Based on the results of the findings, the following conclusions were made: farmers in the study area have diverse socio-economic characteristics with majority $(91 \%)$ still smallscale farmers. It was also ascertained that cotton farming is a profitable venture in the study area considering the results of gross margin analysis and the return on invested.

\section{Acknowledgement}

The authors are grateful to Director and Head, Post Graduate Institute of Agri-Business Management, Junagadh Agriculture University, Junagadh for providing necessary facilities and help to carry out the study.

\section{References}

Alam, M. K., Aboki, E., Gidado, E.H. and Buba, D. D. (2013). Economic Analysis of Cotton Production in Selected Local Government Areas of Taraba State, Nigeria. J AgriSci, 4(1): 27-31.

Ibrahim, M.S. (2002). Resource Use Efficiency in Small Scale Cotton Production in Adamawa State Nigeria. MSc Thesis, Unpublished. Federal University of Technology, Yola.

Ibrahim, E.J. 2008.Economics of Sole Cotton Production in Lau Local Government Area of Taraba State, Nigeria. M.Sc Thesis. Federal University of Technology, Yola, pp. 50-52.

Onu, J.I. and Edon, A. (2009). Comparative economic analysis of improved and local cassava varieties in selected Local Government Areas of Taraba State, Nigeria. Journal of Social Science, 19(3): 213-217.

United State Agency for International Development (2012).Global Cotton Production Trend. From $<\mathrm{http} / /$ www.Usaid $>$ (Retrieved January, 2013).

International Cotton Association Committee (ICAC) (2001).An Overview of the Performance of Extension Services to Cotton Farmers in the Northern Cotton Producing Zone. Proceedings of the Seminar on Cotton Production and Marketing in Nigeria, 10-11 November, Held at Federal Secretariat 
Conference Hall, Bauchi, Nigeria.

Fortucci, P. (2002). The Contribution of Cotton to Economy and Food Security in Developing Countries. A paper
Presented at the Conference of Cotton and Global Trade Negotiation, Ibadan, Nigeria, $20^{\text {th }}$ September, pp. 5-8.

\section{How to cite this article:}

Sanjiv Kumar, C.R. Bharodia, Sarita Meena and BhupendrSingh Tyagi. 2019. Study of the Socio- economic Characteristics of BT Cotton Farmers in Beawer Area in Ajmer District of Rajasthan. Int.J.Curr.Microbiol.App.Sci. 8(11): 1593-1604. doi: https://doi.org/10.20546/ijcmas.2019.811.184 